\title{
Partisipasi Kelompok Perempuan Peduli Lingkungan dalam Penanganan Sampah di Sub DAS Cikapundung, Provinsi Jawa Barat
}

\section{Participation of the Women's Group of Environmental Care Waste Management in Sub River Basin Cikapundung, West Java Province}

\author{
Helnafri Ankesa ${ }^{1}$, Siti Amanah², Pang S. Asngari² \\ ${ }^{1}$ Universitas Nahdlatul Ulama Sumatera Utara, Medan \\ ${ }^{2}$ Departemen Sains Komunikasi dan Pengembangan Masyarakat, Fakultas Ekologi Manusia, \\ Institut Pertanian Bogor, Bogor
}

\begin{abstract}
Waste management need support from community. The issue of waste is also found in Cikapundung river basin. The environmental issue in Cikapundung Sub River Basin motivated women to participate in the form of group movement. The study aims to: (1) identify the group characteristics and (2) analyze the factors that affect the efforts of housewife to maintain Cikapundung Sub River Basin trough movement women group. The study was conducted from March until April 2015 involving 106 respondents of population of 728 women group members and non members. The data was gathered from March to April 2015 in three area: Sunten Jaya Village (upstream), Lebak Siliwangi Village (middle stream) and Dayeuh Kolot Village (down stream). Interview using questionnaire, in-depth interviews, observation, and group discussion were used to collect data. Rank-Spearmann Correlation was used to test level of correlation among the following variables: a) group profiles and dynamic, b) family support, c) the perception and participation of women groups in caring the environment. The results show that the willingness, and the ability of women groups to process the waste are the factors that increase participation. However, most women do not have the same opportunity to participate in the environmental group. group profiles and dynamic, the family support, external support from the leaders and extension program. Were significantly correlate to the level of women perception and participation on environmental group.
\end{abstract}

Keywords: Participation, women groups, waste management, environmental group, extension

\begin{abstract}
Abstrak
Pengelolaan sampah membutuhkan dukungan dari masyarakat. Isu tentang sampah juga di temukan di Sub DAS Cikapundung. Isu lingkungan di Cikapundung Sub DAS telah mengundang perempuan untuk berpartisipasi dalam bentuk gerakan kelompok. Partisipasi masyarakat dalam pengelolaan sampah sangat penting. Penelitian ini bertujuan untuk: (1) mengidentifikasi karakteristik kelompok dan (2) menganalisis faktor-faktor yang mempengaruhi upaya ibu rumah tangga dalam menjaga gerakan kelompok peduli lingkungan di Sub DAS Cikapundung. Penelitian dilakukan dari bulan Maret hingga April 2015 yang melibatkan 106 responden dari kelompok perempuan peduli lingkungan. Kelompok-kelompok yang terletak di tiga wilayah: Sunten Jaya Desa (hulu DAS), Lebak Siliwangi Desa (tengah DAS) dan Dayeuh Kolot Desa (hilir DAS). Wawancara menggunakan kuesioner, wawancara mendalam, observasi, dan diskusi kelompok yang digunakan untuk mengumpulkan data. Korelasi Rank-Spearman digunakan untuk menguji tingkat korelasi antara variabel-variabel berikut: a) profil dan dinamika kelompok, b) dukungan keluarga, c) persepsi dan partisipasi kelompok wanita peduli lingkungan. Hasil penelitian menunjukkan bahwa kemauan, dan kemampuan kelompok wanita untuk mengolah limbah adalah faktor yang meningkatkan partisipasi. Mayoritas wanita tidak memiliki kesempatan yang sama untuk berpartisipasi dalam kelompok peduli lingkungan. Faktor yang signifikan dengan tingkat persepsi dan partisipasi wanita dalam kelompok peduli lingkungan adalah profil dan dinamika kelompok, dukungan keluarga, dukungan tokoh masyarakat dan program penyuluhan.
\end{abstract}

Kata kunci: Partisipasi, kelompok wanita, pengelelolahan sampah, peduli lingkungan, penyuluh

\section{Pendahuluan}

Kondisi lingkungan di Sub DAS Cikapundung menunjukkan penurunan kualitas, hal ini disebabkan oleh berbagai faktor baik dari alam maupun manusia. Perilaku membuang sampah yang tidak semestinya memperburuk kondisi sungai. Artiningsih (2008) menyatakan bahwa pada tahun 1995 jumlah sampah yang dihasilkan di Indonesia adalah 800 gram/hari/kapita dan meningkat menjadi 910 gram/hari/kapita pada tahun 2010. Hal ini ditemui pula pada Sub DAS Cikapundung. Tercemarnya Sub DAS Cikapundung akibat limbah rumah tangga, limbah ternak, limbah industri, penggarapan lahan sekitar Sub DAS Cikapundung yang tidak terkendali 
dengan baik, penebangan pohon dan alih fungsi lahan sehingga menyebabkan lonsor, pendangkalan sungai dan semakin meningkatnya laju koefisien limpasan (runoff) dan menurunnya aliran infiltrasi serta baseflow di DAS. Rasyidi (2009), menyatakan bahwa perkembangan pemanfaatan lahan di DAS Cikapundung Hulu saat ini telah memperlihatkan kondisi yang mengkhawatirkan. Masyarakat sebagai elemen yang paling dekat dan paling mempengaruhi kondisi Sub DAS Cikapundung perlu menyadari pentingnya kesadaran peduli lingkungan bersih dan sehat. Peran serta baik laki-laki maupun perempuan sangat diperlukan untuk menekan tingkat kerusakan. Selama ini yang banyak terlibat dalam pembangunan aspek fisik lingkungan adalah laki-laki, namun diharapkan perempuan juga dapat terlibat aktif dalam kegiatan sosial diluar kegiatan domestik, maka munculah gerakan perempuan peduli lingkungan. Kendalanya adalah bahwa sebagian besar curahan waktu perempuan adalah mengurus rumah tangga, sedangkan partisipasi aktif ibu rumah tangga dalam kegiatan peduli lingkungan merupakan modal sosial yang perlu dikembangkan.

Munculnya gerakan peduli lingkungan oleh kelompok perempuan di tiga wilayah Sub DAS Cikapundung (hulu, tengah dan hilir) merupakan respon dari masyarakat terhadap masalah lingkungan. Kelompok tersebut merupakan wadah menyalurkan pikiran, ide dan tenaga untuk mewujudkan aksi peduli Sub DAS Cikapundung mulai dari hulu sampai hilir. Kesadaran masyarakat akan pentingnya kelompok peduli lingkungan secara tidak langsung meningkatkan partisipasi masyarakat terhadap kegiatan peduli lingkungan. Dua dari tiga kelompok di atas memiliki anggota ibu rumah tangga yang solid dan paling aktif tingkat wilayahnya masing-masing yaitu kelompok di Desa Dayeuh Kolot dan Kelurahan Lebak Siliwangi, sedangkan kelompok di Desa Sunten Jaya merupakan kelompok wanita satusatunya di Desa Sunten Jaya.

Menurut Slamet (1985) tumbuh dan berkembangnya partisipasi masyarakat dalam pembangunan sangat ditentukan oleh tiga unsur pokok, yaitu adanya kemauan, kemampuan dan kesempatan. Keberlanjutan gerakan kelompok perempuan peduli lingkungan sangat tergantung kepada dinamika kelompok itu sendiri. Kendala yang ditemui perempuan dalam perkembangan kelompok peduli lingkungan menurut Amanah et al., (2013), adalah keterbatasan dalam mengakses informasi dan inovasi teknologi pengolahan sampah. Selain itu penyuluh atau agen perubahan belum banyak terlibat dalam pengembangan kelompok peduli lingkungan di tiga lokasi penelitian. Berdasar latar belakang tersebut, fokus permasalahan penelitian adalah (i) bagaimana profil kelompok perempuan peduli lingkungan dalam mengelola kegiatannya, dan (ii) apa saja yang pendorong partisipasi kelompok perempuan perduli lingkungan mengelola sampah di Sub DAS Cikapundung tersebut?

\section{Metode Penelitian}

Metode survei digunakan untuk memperoleh data dan informasi dari ibu-ibu anggota kelompok perempuan peduli lingkungan di Sub DAS Cikapundung. Data lapang dikumpulkan mulai Maret sampai dengan April 2015. Lokasi pengambilan data adalah di hulu, tengah, dan hilir Sub DAS Cikapundung dengan mengambil Desa Sunten Jaya, Kelurahan Lebak Siliwangi dan Desa Dayeuh Kolot. Responden sampel adalah seluruh perempuan yang terlibat dalam gerakan kelompok peduli lingkungan di tiga wilayah penelitian dan sebanyak 106 orang (53 orang responden IRT non anggota kelompok diambil secara acak dan 53 orang IRT anggota kelompok peduli lingkungan diambil secara sengaja) dari populasi sebesar 728 orang.

Kuesioner digunakan untuk mendapatkan data dari wawancara responden. Jawaban atas pertanyaan kuesioner diberi skor (skala ordinal). Wawancara mendalam dan observasi lapang digunakan juga untuk mendapat data dan informasi mengenai pengelolaan lingkungan. Adapun variabel dalam penelitian ini adalah profil KPL $\left(\mathrm{X}_{1}\right)$, tingkat dukungan keluarga $\left(\mathrm{X}_{2}\right)$ yang meliputi peran ibu dalam keluarga, peran dalam masyarakat, perhatian ibu terhadap keluarga, pendapat keluarga tentang peran ibu dan kegiatan rutin ibu seharihari. Tingkat kedinamisan kelompok $\left(\mathrm{X}_{3}\right)$ meliputi struktur kelompok dan interaksi kelompok. Persepsi $\left(\mathrm{X}_{4}\right)$ dan tingkat partisipasi ibu rumah tangga kelompok peduli lingkungan (Y) di tahapan perencanaan, pelaksanaan, dan tahap monitoring dan evaluasi dilihat dari unsur yang meliputi kemauan, kesempatan dan kemampuan. Uji korelasi Rank-Spearman digunakan untuk menganalisis keterkaitan antara variabel $\mathrm{X}$ dan variabel $\mathrm{Y}$.

\section{Hasil dan Pembahasan}

\section{Profil Ibu Rumah Tangga Responden}

Variasi umur pada setiap wilayah penelitian cukup beragam. Umur ibu rumah tangga di wilayah 
hulu sebagian besar termasuk kategori umur muda. Hasil observasi lapangan mengungkapkan bahwa ibu rumah tangga di wilayah hulu kebanyakan menikah muda. Remaja di desa ini kurang memiliki semangat menempuh pendidikan formal lebih tinggi seperti halnya pemuda pemudi di wilayah tengah dan hilir daerah penelitian, hal ini disebabkan karena berbagai faktor salah satunya faktor ekonomi.

Pendidikan non formal yang pernah diikuti oleh ibu rumah tangga di wilayah hulu (Desa Sunten Jaya) dalam dua tahun terahir hampir tidak pernah, hal ini disebabkan tidak adanya program pemerintah daerah setempat yang dijalankan dan kesadaran dari warga sendiri untuk ikut dalam pelatihan atau kursus dan sejenisnya. Hal ini juga ditemukan di wilayah tengah dan hillir daerah penelitian (Kelurahan Lebak Siliwangi dan Desa Dayeuh Kolot), warga kurang berminat untuk mengikui kegiatan pendidikan non formal dari desa atau kelurahan masing-masing karena keterbatasan waktu dari ibu rumah tangga saat itu. Tingkat pendidikan ibu rumah tangga mempengaruhi tingkat partisipasi dalam suatu kegiatan. Semakin tinggi pendidikan seseorang maka semakin mudah dan cepat dalam penyerapan informasi dan pembinaan (Pangestu, 1995). Persentase ibu rumah tangga menurut profil ibu rumah tangga disajikan pada
Tabel 1.

Berdasarkan tingkat pendapatan ibu rumah tangga masih di bawah UMK yaitu Rp.2.310.000,- per bulan. Tingkat pendapatan responden di Kelurahan Lebak Siliwangi dominan lebih tinggi dari wilayah penelitian lainnya karena kelurahan ini terletak di kota yang memiliki potensi lebih besar untuk mendapatkan pekerjaan yang lebih baik bagi warga sekitarnya. Menurut Budiman (2013), pendapatan keluarga masyarakat akan mempengaruhi kreativitas dan pengorbanan keluarga tersebut terhadap aktivitas atau kegiatan dalam menjaga dan mengelola lingkungan sekitar tempat tinggalnya.

\section{Tingkat Dukungan Keluarga}

Dominan ibu rumah tangga di wilayah hulu dan hilir penelitian adalah ibu rumah tangga biasa baik perannya dalam keluarga maupun dalam masyarakat. Peran ibu rumah tangga yang lebih sering di rumah sehingga perhatian ibu rumah tangga juga lebih banyak pada kegiatan domestik dari pada kegiatan publik. Berbeda dengan ibu rumah tangga di Keluarahan Lebak Siliwangi, hasil observasi di lapangan sebagian besar ibu rumah tangga dapat menyeimbangkan kegiatan publik

Tabel 1. Persentase Ibu Rumah Tangga menurut Profil Ibu Rumah Tangga di Sub DAS Cikapundung

\begin{tabular}{|c|c|c|c|c|}
\hline No & Variabel & $\begin{array}{c}\text { Sunten Jaya } \\
(\%)\end{array}$ & $\begin{array}{c}\text { Lebak Siliwangi } \\
(\%)\end{array}$ & $\begin{array}{c}\text { Dayeuh Kolot } \\
(\%)\end{array}$ \\
\hline \multirow[t]{5}{*}{1} & Umur: & & & \\
\hline & (1) Tua ( $\geq 43$ tahun) & 11,54 & 10,00 & 45,00 \\
\hline & (2) Dewasa (34 - 42 tahun) & 15,38 & 50,00 & 33,33 \\
\hline & (3) Muda ( $\leq 33$ tahun) & 73,08 & 40,00 & 21,67 \\
\hline & Total & 100,00 & 100,00 & 100,00 \\
\hline \multirow[t]{5}{*}{2} & Tingkat Pendidikan Formal: & & & \\
\hline & (1) Diploma/Sarjana & 0,00 & 40,00 & 31,67 \\
\hline & (2) SMP-SMA & 34,62 & 35,00 & 50,00 \\
\hline & (3) $\mathrm{SD}$ & 65,38 & 25,00 & 18,33 \\
\hline & Total & 100,00 & 100,00 & 100,00 \\
\hline \multirow[t]{5}{*}{3} & Pendidikan non formal: & & & \\
\hline & (1) $>3$ kali & 7,69 & 15,00 & 11,67 \\
\hline & (2) $1-2$ kali & 26,92 & 10,00 & 21,67 \\
\hline & (3) Tidak pernah & 65,38 & 75,00 & 66,67 \\
\hline & Total & 100,00 & 100,00 & 100,00 \\
\hline \multirow[t]{5}{*}{4} & Tingkat Pendapatan: & & & \\
\hline & (1) Tinggi $(\geq R p$ 1.433.000) & 34,62 & 50,00 & 13,33 \\
\hline & $\begin{array}{l}\text { (2) Sedang (Rp 736.000 - } \\
\text { Rp 1.432.000) }\end{array}$ & 34,62 & 30,00 & 65,00 \\
\hline & (3) Rendah $(\leq \operatorname{Rp} 735.000)$ & 30.77 & 20.00 & 21.67 \\
\hline & Total & 100,00 & 100,00 & 100,00 \\
\hline
\end{tabular}


dan kegiatan domestik karena adanya dorongan dan motivasi dari tokoh masyarakat yang juga aktif dalam kelompok gerakan perempuan.

Dominan ibu rumah tangga di tiga wilayah penelitian mendapat dukungan dan motivasi dari keluarga berupa izin dan keluarga tidak banyak menuntut ibu untuk tetap bekerja di dalam rumah. Menurut anggota keluarga dengan aktifnya ibu rumah tangga terhadap kegiatan publik yang sedang ditekuni dapat meningkatkan kemajuan dan pengembangan pengetahuan ibu rumah tangga itu sendiri. Persentase tingkat dukungan keluarga terhadap ibu rumah tangga disajikan pada Tabel 2.

Meskipun mendapat dukungan dari keluarga, namun dari hasil observasi lapangan kondisi IRT di DAS Cikapundung masih banyak melakukan kegiatan domestik dari pada kegiatan publik, lain halnya dengan kaum laki-laki. Warga masih beranggapan bahwa pembagian peran dalam rumah tangga adalah kaum lakilaki bekerja di luar rumah dan perempuan mengurus semua kegiatan di rumah, sehingga kaum laki-laki tidak merasa berkewajiban untuk membantu urusan domestik. Hal ini menjadi salah satu penghalang bagi ibu rumah tangga untuk aktif dalam kegiatan publik dengan alasan kemampuan dan kesempatan yang terbatas.

\section{Tingkat Kedinamisan Kelompok}

Struktur kelompok peduli lingkungan ditiga wilayah penelitian hampir sama. Kelompok di Desa Sunten Jaya yang diberi nama kelompok Sadulur Satujuan merupakan kelompok kerajinan daur ulang samapah yang pada mulanya dibentuk bertujuan agar lebih muda mendapatkan bantuan dari pemerintahan setempat. Kelompok di Kelurahan Lebak Siliwangi yang bernama kelompok Bank Sampah RW 08 dibentuk oleh salah seorang tokoh masyarakat yang menginginkan perubahan perilaku hidup bersih di wilayahnya sehingga dibentuklah kelompok Bank

Tabel 2. Persentase Besaran Dukungan Keluarga kepada Ibu Rumah Tangga

\begin{tabular}{|c|c|c|c|c|}
\hline No & Variabel & $\begin{array}{c}\text { Sunten Jaya } \\
(\%)\end{array}$ & $\begin{array}{l}\text { Lebak Siliwangi } \\
(\%)\end{array}$ & $\begin{array}{c}\text { Dayeuh Kolot } \\
(\%)\end{array}$ \\
\hline \multirow[t]{5}{*}{1} & Peran dalam keluarga: & & & \\
\hline & (1) Ibu rumah tangga biasa & 46,15 & 45 & 83,33 \\
\hline & $\begin{array}{l}\text { (2) Ikut mencari nafkah membantu } \\
\text { suami }\end{array}$ & 50,00 & 45 & 15,00 \\
\hline & $\begin{array}{l}\text { (3) Sebagai kepala keluarga sekaligus } \\
\text { tulang punggung keluarga }\end{array}$ & 3,85 & 10 & 1,67 \\
\hline & Total & 100,00 & 100 & 100,00 \\
\hline \multirow[t]{5}{*}{2} & Peran dalam masyarakat: & & & \\
\hline & (1) Sebagai warga biasa & 96,15 & 50 & 75,00 \\
\hline & (2) Istri dari tokoh masyarakat & 3,85 & 25 & 13,33 \\
\hline & (3) Sebagai tokoh masyarakat & 0,00 & 25 & 11,67 \\
\hline & Total & 100,00 & 100 & 100,00 \\
\hline \multirow[t]{5}{*}{3} & Perhatian terhadap keluarga: & & & \\
\hline & $\begin{array}{l}\text { (1) Lebih banyak melakukan kegiatan } \\
\text { sosial }\end{array}$ & 30,77 & 10 & 13,33 \\
\hline & (2) Lebih banyak kegiatan di rumah & 38,46 & 40 & 60,00 \\
\hline & $\begin{array}{l}\text { (3) Seimbang antara kegiatan sosial } \\
\text { dan di rumah }\end{array}$ & 30,77 & 50 & 26,67 \\
\hline & Total & 100,00 & 100 & 100,00 \\
\hline \multirow[t]{4}{*}{4} & $\begin{array}{l}\text { Pendapat keluarga tentang peran ibu: } \\
\text { (1) Tidak setuju jika ibu ada kegiatan } \\
\text { sosial di luar rumah }\end{array}$ & 0 & 10 & 13,33 \\
\hline & (2) Kurang setuju jika ibu ada & 0 & 25 & 15,00 \\
\hline & $\begin{array}{l}\text { kegiatan sosial di luar rumah } \\
\text { (3) Setuju jika ibu punya kegiatan } \\
\text { sosial di luar rumah }\end{array}$ & 100 & 65 & 71,67 \\
\hline & Total & 100,00 & 100 & 100,00 \\
\hline
\end{tabular}


Tabel 3. Persentase Tingkat Pelaksanaan Kepemimpinan Formal, Peran dan Tugas serta Norma Kelompok

\begin{tabular}{|c|c|c|c|c|}
\hline No & Variabel & $\begin{array}{c}\text { Sunten } \\
\text { Jaya (\%) }\end{array}$ & $\begin{array}{c}\text { Lebak } \\
\text { Siliwangi } \\
(\%)\end{array}$ & $\underset{(\%)}{\text { Dayeuh Kolot }}$ \\
\hline \multirow[t]{5}{*}{1} & Kepemimpinan formal & & & \\
\hline & (1) Rendah (skor 7-11) & 46,15 & 0 & 3,33 \\
\hline & (2) Sedang (skor $12-16$ ) & 38,46 & 20 & 16,67 \\
\hline & (3) Tinggi (skor $17-21$ ) & 15.38 & 80 & 80.00 \\
\hline & Total & 100,00 & 100 & 100,00 \\
\hline \multirow[t]{5}{*}{2} & $\begin{array}{l}\text { Peran dan tugas setiap anggota dan } \\
\text { pengurus }\end{array}$ & & & \\
\hline & (1) Rendah (skor 7-11) & 7,69 & 0 & 0 \\
\hline & (2) Sedang (skor $12-16$ ) & 92,31 & 0 & 16,67 \\
\hline & (3) Tinggi (skor $17-21$ ) & 0,00 & 100 & 83,33 \\
\hline & Total & 100,00 & 100 & 100,00 \\
\hline \multirow[t]{5}{*}{3} & Kepatuhan terhadap norma yang dianut klp & & & \\
\hline & (1) Tidak diterapkan & 92,31 & 00 & 0 \\
\hline & (2) Tidak selalu diterapkan & 7,69 & 10 & 26,67 \\
\hline & (3) Selalu diterapkan & 0,00 & 90 & 73,33 \\
\hline & Total & 100,00 & 100 & 100,00 \\
\hline
\end{tabular}

Sampah di mana kelompok tersebut merupakan anggota dari pengajian yang sudah ada di RW 08 Lebak Siliwangi. Kelompok KRPL (Kelompok Rumah Pangan Lestari) di Desa Dayeuh Kolot sudah cukup lama terbentuk. Kelompok KRPL ini juga merangkap kegiatan Bank Sampah di agenda KRPL.

Kepemimpinan formal Kelompok di desa Sunten Jaya berada pada kategori rendah (Tabel 3). Ibu rumah tangga responden menyatakan bahwa "kelompok kurang mendapatkan motivasi dan teladan yang baik dari ketua". Hal ini berpengaruh terhadap peran dan tugas serta kepatuhan terhadap norma dalam kelompok bagi anggota. Dominan anggota di kelompok Desa Sunten Jaya masih belum menjalankan peran dan tugas masing-masing serta tidak mematuhi norma yang ada. Alfando (2013) mengungkapkan bahwa cara mengatasi belum maksimalnya fungsi tugas di dalam kelompok adalah dilakukannya rapat yang rutin, mengadakan evaluasi anggota, serta mengevaluasi struktur kelompok.

Dinamikakelompok dilihat dariinteraksi, anggota dan pengurus kelompok di Kelurahan Lebak Siliwangi memiliki pengalaman berorganisasi yang cukup lama, sehingga interaksi kelompok antar anggota dan pengurus yang cukup intens dan sering dalam jangka waktu panjang mampu memotivasi anggota kelompok untuk tetap aktif berpartisipasi dalam kelompok. Intensitas interaksi dapat mempengaruhi kejelasan komunikasi disetiap kelompok semakin sering interaksi yang berlangsung semakin jelas informasi yang dikomunikasikan. Kondisi ini sinkron dengan hasil penelitian Hidayat (2013) yang mengungkapkan bahwa rutinnya interaksi sosial yang dibangun oleh kelompok dapat membangun komunikasi dan interaksi yang baik. Hal ini sesuai dengan kondisi di kelompok Sadulur Satujuan, minimnya interaksi di dalam dan luar kelompok berdampak pada kejelasan komunikasi dan keaktifan interaksi anggota kelompok. Hal serupa ditemukan dalam penelitian Kusnani (2015), bahwa belum maksimalnya interaksi yang dibangun oleh kelompok dengan elemen di dalam masyarakat menyebabkan komunikasi di dalam maupun luar kelompok belum berlangsung baik sehingga proses mendapatkan informasi yang dibutuhkan kelompok menjadi lambat.

Keaktifan interaksi anggota dan pengurus juga tergantung keakraban yang terjalin dalam kelompok. Hasil wawancara dan observasi di lapangan, kelompok yang anggotanya memiliki hubungan keakraban yang erat satu sama lain akan lebih aktif berinteraksi satu sama lain. Hal ini sejalan dengan pendapat Wahid (2008) bahwa hubungan antara pengurus kelompok dengan instansiinstansi terkait dalam hal pelaksanaan kegiatan oleh anggotanya yang sangat berpengaruh terhadap dinamika kelompok. Berdasarkan interaksi maka persentase dinamika kelompok ditampilkan pada Tabel 4.

\section{Persepsi Ibu Rumah Tangga terhadap Pengelolaan Sampah}

Terdapat perbedaan persepsi terhadap pengelolaan sampah oleh responden anggota kelompok peduli lingkungan dengan persepsi bukan anggota kelompok.Persepsiiburumahtanggaanggotakelompok 
Tabel 4. Persentase Kelompok menurut Interaksi di Sub DAS Cikapundung

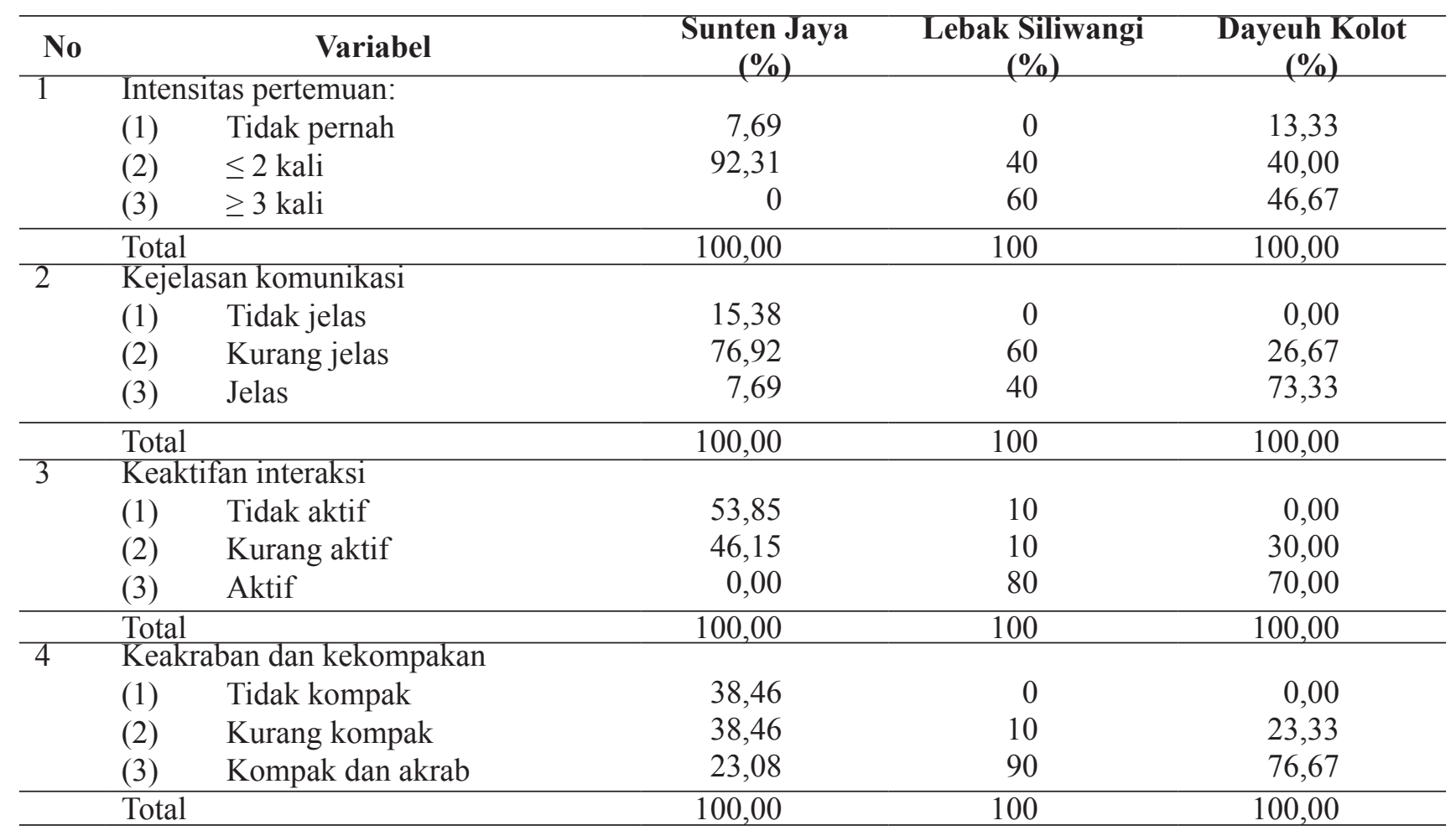

peduli lingkungan ada pada tingkat tinggi yaitu 3,50 sedangkan persepsi ibu rumah tangga non anggota ada pada tingkat sedang yaitu sebesar 2,96 (Tabel 5). Ibu rumah tangga responden cenderung tidak setuju jika sampah yang sulit dikumpulkan dan dipilah tidak boleh dibakar. Warga lebih suka membakar sampah agar tidak berserakan dan mengotori lingkungan. Hal ini terjadi karena kurangnya pengetahuan warga tentang bahaya asap yang ditimbulkan dari pembakaran sampah.

Ibu rumah tangga anggota kelompok memiliki persepsi yang baik terhadap sikap malu jika membuang sampah sembarangan dan memualai pola hidup bersih mulai dari keluarga sendiri. Berbeda dengan ibu rumah tangga bukan anggota kelommpok. Mereka lebih setuju dengan pernyataan sampah rumah tangga mudah dikumpulkan dalam suatu wadah dan mulai membiasakan diri untuk hidup bersih mulai dari keluarga sendiri.

\section{Tingkat Partisipasi Ibu Rumah Tangga Kelompok Peduli Lingkungan}

Ibu rumah tangga memiliki minimal satu unsur partisipasi dalam setiap tahapan partisipasi kelompok. Setiap unsur partisipasi yang dimiliki ibu rumah tangga bisa saling mendukung satu sama lain atau sebaliknya. Ibu rumah tangga yang memiliki unsur kemauan cenderung akan berusaha mencari kesempatan yang ada untuk ikut dalam partisipasi kelompok. Ibu rumah tangga yang tidak memiliki kemampuan akan mempengaruhi kemauannya untuk ikut berpartisipasi dalam kelompok.

Masyarakatyang bukan anggotakelompokpeduli lingkungan banyak yang tidak memiliki kesempatan dalam perencanaan kelompok peduli lingkungan. Hal ini terjadi karena kebanyakan responden tidak diberi informasi yang lengkap oleh anggota yang memiliki akses informasi yang lebih luas. Persentase tingkat partisipasi IRT kelompok peduli lingkungan menurut tahap perencanaan, pelaksanaan, monitoring dan evaluasi disajikan dalam Tabel 6.

Pada tahap pelaksanaan banyak responden memiliki kemampuan dari pada kemauan untuk ikut serta dalam pelaksanaan kegiatan kelompok peduli lingkungan, ini disebabkan adanya konflik sosial yang terjadi antara ibu rumah tangga responden di dalam masyarakat. Tahap monitoring kegiatan kelompok peduli lingkungan, dari hasil analisis menunjukan bahwa hampir seluruh responden memiliki unsur partisipasi yang cukup tinggi.

Penelitian Yuliastuti (2013) juga mengungkapkan hal yang sama, bahwa terdapat hubungan searah antara kemauan masyarakat dan partisipasi masyarakat. Jika kemauan masyarakat meningkat, maka partisipasi masyarakat juga meningkat. Kemauan masyarakat yang tinggi dapat meningkatkan partisipasi masyarakat 
Jurnal Penyuluhan, September 2016 Vol. 12 No. 2

Tabel 5. Tingkat Skor Persepsi Anggota dan Non Anggota Kelompok Peduli Lingkungan

\begin{tabular}{ccccccccccc}
\hline \multirow{2}{*}{ Pernyataan } & \multicolumn{4}{c}{ Anggota (53 orang) } & \multicolumn{5}{c}{ Non Anggota (53 orang) } \\
\cline { 2 - 11 } & TS & KS & S & SS & P & TS & KS & S & SS & P \\
\hline 1 & 0 & 3 & 17 & 33 & 3,57 & 0 & 0 & 24 & 29 & 3,55 \\
2 & 1 & 2 & 20 & 30 & 3,49 & 2 & 18 & 18 & 15 & 2,87 \\
3 & 0 & 12 & 10 & 31 & 3,36 & 0 & 33 & 13 & 7 & 2,51 \\
4 & 1 & 3 & 18 & 31 & 3,49 & 1 & 13 & 29 & 10 & 2,91 \\
5 & 9 & 6 & 16 & 22 & 2,96 & 29 & 7 & 12 & 5 & 1,87 \\
6 & 2 & 3 & 14 & 34 & 3,51 & 4 & 4 & 22 & 23 & 3,21 \\
7 & 2 & 3 & 17 & 31 & 3,45 & 4 & 17 & 14 & 18 & 2,87 \\
8 & 1 & 0 & 19 & 33 & 3,58 & 7 & 7 & 15 & 24 & 3,06 \\
9 & 0 & 0 & 13 & 40 & 3,75 & 0 & 3 & 34 & 16 & 3,25 \\
10 & 0 & 0 & 10 & 43 & 3,81 & 0 & 2 & 22 & 29 & 3,51 \\
\hline Rerata P & \multicolumn{4}{c}{3,50} & \multicolumn{7}{c}{2,96} & \\
\hline
\end{tabular}

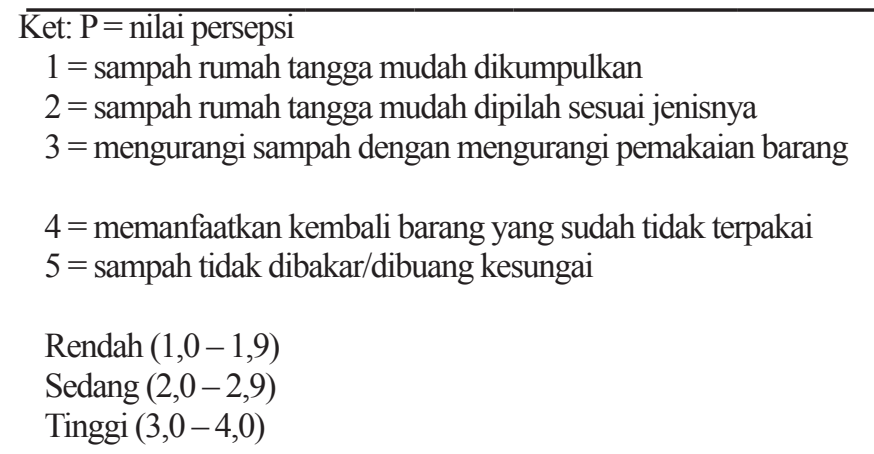
$6=$ sampah organik didaur ulang menjadi pupuk tanaman
$7=$ sampah anorganik didaur ulang menjadi kerajinan tangan
$8=$ sampah yang didaur ulang menjadi pendapatan tambahan keluarga
$9=$ malu jika masih membuang sampah sembarangan
$10=$ membiasakan diri untuk hidup bersih mulai dari keluarga sendiri

dalam pengelolaan sampah. Masyarakat sudah sangat menyadari akan adanya dampak kerusakan lingkungan yang akan terjadi apabila masyarakat tidak memiliki kemauan untuk mengurangi pencemaran akibat sampah yang terjadi.

\section{Faktor-Faktor yang Berhubungan dengan Tingkat Partisipasi Ibu Rumah Tangga Kelompok Peduli Lingkungan}

Faktor-faktor yang berhubungan nyata dengan persepsi ibu rumah tangga terhadap pengelolaan sampah adalah umur $\left(\mathrm{r}_{\mathrm{s}}:-0,308^{* *}\right)$, tingkat pendidikan formal $\left(r_{\mathrm{s}}: 0,289 * *\right)$ dan pengetahuan ibu rumah tangga $\left(\mathrm{r}_{\mathrm{s}}\right.$ : $\left.0,353^{* *}\right)$. Hasil penelitian menunjukkan bahwa umur, tingkat pendidikan formal dan pengetahuan memiliki hubungan yang sangat nyata dengan persepsi ibu rumah tangga terhadap pengelolaan sampah. Umur memiliki hubungan negatif sangat nyata dengan tingkat partisipasi

Tabel 6. Persentase Partisipasi IRT di Sub DAS Cikapundung menurut Tiga Tahapan Partispasi

\begin{tabular}{lccc}
\hline \multicolumn{1}{c}{ Variabel } & Sunten Jaya (\%) & Lebak Siliwangi (\%) & Dayeuh Kolot (\%) \\
\hline (1) Perencanaan: & 76.92 & 100 & 100.00 \\
- Kemauan & 42.31 & 50 & 60.00 \\
- Kesempatan & 73.08 & 100 & 93.33 \\
(2) Pemampuan & & & \\
- Kemauanan: & 50.00 & 100 & 65.00 \\
- Kesempatan & 80.77 & 75 & 86.67 \\
- Kemampuan & 88.46 & 100 & 100.00 \\
(3) Monitoring dan & & & \\
- Evaluasi: & 61.54 & 100 & 60.00 \\
- Kemauan & 57.69 & 60 & 100.00 \\
- Kesempatan & 92.31 & 100 & \\
Ket: setiap responden boleh memilih lebih dari satu unsur partisipasi & &
\end{tabular}


IRT, maka muda umur ibu rumah tangga maka semakin tidak peduli terhadap lingkungan sehingga semakin rendah tingkat persepsi yang dimiliki ibu rumah tangga terhadap pengelolaan sampah

Semakin tinggi tingkat pendidikan formal ibu rumah tangga, semakin tinggi pula tingkat pengetahuan ibu rumah tangga dan tentunya semakin mudah menerima suatu informasi sehingga meningkatkan persepsi ibu rumah tangga terhadap kegiatan kelompok peduli lingkungan. Hal ini sejalan dengan hasil penelitian yang dilakukan oleh Notoatmodjo (2007), bahwa dengan tingkat pendidikan yang tinggi akan meningkatkan pengetahuan responden tentang pentingnya pengelolaan sampah.

Faktor-faktoryang berhubungan dengan tingkat partisipasi dilihat dari faktor internal, eksternal dan persepsi ibu rumah tangga. Berdasarkan faktor internal yang berhubungan nyata dengan tingkat partisipasi adalah Umur ( $\left.\mathrm{r}_{\mathrm{s}}:-0,269^{* *}\right)$, tingkat pendidikan formal $\left(\mathrm{r}_{\mathrm{s}}: 0,200^{*}\right)$ dan pengetahuan ibu rumah tangga $\left(\mathrm{r}_{\mathrm{s}}\right.$ : $0,452 * *)$. Umur memiliki hubungan negatif dengan tingkat partisipasi maka dapat disimpulkan bahwa semakin muda IRT maka semakin rendah tingkat partisipasi pengelolaan sampah. Hal ini disebabkan karena IRT yang sudah tua memiliki waktu yang lebih banyak dari pada IRT yang masih muda.

Tingkat pendidikan formal berhubungan sangat nyata terhadap partisipasi ibu rumah tangga, semakin tinggi tingkat pendidikan IRT maka semakin tinggi pula tingkat partisipasi ibu rumah tangga terhadap kegiatan kelompok peduli lingkungan, begitu pula sebaliknya. Ibu rumah tangga yang memiliki tingkat pendidikan lebih tinggi cenderung lebih suka memiliki kegiatan di luar rumah, karena menurut mereka ilmu dan pengalaman di sekolah dapat diaplikasikan dalam kelompok.

Faktor eksternal yang berhubungan nyata dengan tingkat partisipasi adalah tingkat dukungan keluarga $\left(\mathrm{r}_{\mathrm{s}}\right.$ : 0,234*) dan tingkat kedinamisan kelompok. Semakin besar dukungan yang diberikan keluarga maka semakin besar pula motivasi ibu rumah tangga untuk berpartisipasi. Semakin kuat dinamika kelompok semakin tinggi tingkat partisipasi IRT. Tingkat kedinamisan kelompok yang semakin baik mulai dari struktur kelompok $\left(\mathrm{r}_{\mathrm{s}}: 0,442 * *\right)$ dan interaksi yang intens membuat anggota dan warga sekitar $\left(\mathrm{r}_{\mathrm{s}}: 0,410^{* *}\right)$ ikut tergerak untuk ikut berpartisipasi dalam kegiatan pengelolaan sampah. Sejalan dengan penelitian yang dilakukan Trihapsari dan Nashori (2011) bahwa karakteristik personal dan struktur di dalam kelompok mempengaruhi tingginya komitmen kerja anggota di dalam kelompok/ organisasi.

\section{Kesimpulan}

Penanganan sampah di Sub DAS Cikapundung bervariasi, yaitu ada yang penanganan sampah dengan cara mendaur ulang sampah anorganik menjadi kerajinan tangan dan sampah organik menjadi pupuk, selain itu dengan mengumpulkan dan memilah sampah untuk ditabung di Bank Sampah. Kelompok sampah yang digerakkan ibu-ibu ada di seluruh lokasi Sub DAS Cikapundung yaitu Kelompok Sadulur Satujuan di hulu Sub DAS Cikapundung yang merupakan kelompok pendaurulangsampahanorganik.KelompokBankSampah di tengah Sub DAS Cikapundung merupakan kelompok yang mengumpulkan dan memilah sampah untuk ditabung, dan kelompok Rumah Pangan Lestari di hilir Sub DAS Cikapundung adalah kelompok yang awalnya memang dibentuk dari program pemerintah namun terus berkembang menjadikelompokibu-ibupeduli lingkungan dalam penanganan sampah. Dapat disimpulkan bahwa dari ketiga kelompok di wilayah penelitian, kelompok Sadulur Satujuan merupakan kelompok yang paling rendah perkembangan kelompoknya sehingga masih perlu mendapatkan pembinaan dari tokoh masyarakat dan penyuluhan. Kelompok Bank Sampah Rw 08 dan Kelompok Rumah Pangan Lestari termasuk kelompok yang cukup berkembang dilihat dari struktur kelompok, interaksi anggota yang intens dan faktor profil anggota yang cukup baik mulai dari umur, tingkat pendidikan formal dan pengetahuan.

Faktor-faktor yang berhubungan positif sangat nyata dengan tingkat partisipasi ibu rumah tangga dalam kegiatan kelompokpeduli lingkungan adalah pengetahuan IRT, struktur kelompok dan interaksi anggota di dalam dan luar kelompok, sedangkan umur berhubungan negatif nyata dengan tingkat partisipasi. Faktor lain yang berhubungan positif nyata adalah tingkat pendidikan formal dan dukungan keluarga.

\section{Daftar Pustaka}

Alfando J. 2013. Peran Kelompok Informasi Masyarakat (KIM) dalam Mewujudkan Desa Mandiri di Desa Sidomulyo Kecamatan Anggana Kutai Kartanegara. Ejournal Ilmu Komunikasi 1(2): 109-125.

Amanah S, Rian E, Faqih A, Herawati T. 2013. Pengelolaan Limbah Domestik yang Berwawasan 
Gender dalam Merespon Perubahan Iklim di Sub DAS Cikapundung. Prosiding Seminar Hasil-Hasil PPM IPB 1: 159-176.

Artiningsih NKA. 2008. Peranserta Masyarakat dalam Pengelolaan Sampah Rumah Tangga (Studi Kasus di Sampingan dan Jomblang, Kota Semarang). Tesis. Semarang: Program Magister Lingkungan Universitas Dionegoro.

Budiman RA. 2013. Partisipasi dan Persepsi Masyarakat dalam Upaya Menjaga Mengelola Lingkungan Hidup dan Mempertahankan Predikat Kota Bersih. Jurnal Ilmu Lingkungan. Tanjung Pinang Kepulauan Riau.

Dian A, Safitri RM. 2011. Hubungan Antara Kohesivitas Kelompok dengan Motivasi Kerja Pegawai Kelurahan di Kecamatan Kabupaten Bantul. Jurnal Insight 9(1): 12-20.

Hidayat. 2013. Teori Kinerja dalam Efektivitas Karyawan. Yogyakarta(ID): UGM.

Johanto A. 2010. "Pengaruh Kondisi Sosial dan Pengetahuan Lingkungan Ibu-ibu Rumah Tangga terhadap Pengelolaan Sampah Rumah Tangga di Kecamatan Nganjuk, Kabupaten Nganjuk.” Artikel Mahasiswa Jurusan Geografi, Fakultas Ilmu Sosial, Universitas Negeri Malang.

Kusnani DK. 2015. Dinamika Kelompok Penerima CSR PLN Tarahan Lampung Selatan. Jurnal Penyuluhan
11(2):129-142

Notoatmodjo. 2007. Kesehatan Masyarakat Ilmu dan Seni. Jakarta (ID). Rineka Cipta.

Pangestu MHT. 1995. Partisipasi dalam Pelaksanaan Kegiatan Perhutanan Sosial (Studi Kasus: KPH Cianjur Jawa Barat). [Tesis]. Bogor (ID): Sekolah Pascasarjana. IPB.

Rasyidi MS. 2009. Menuju Ketersediaan Air yang Berkelanjutan di DAS Cikapundung Hulu: Suatu Pendekatan System Dynamics. Program Studi Pembangunan. [Tesis]. Bogor (ID): Sekolah Pascasarjana. Institut Teknologi Bandung.

Trihapsari V, Nashori F. 2011. Kohesivitas Kelompok dan Komitmen Organisasi Pada Financial Advisor Asuransi ' $\mathrm{X}$ ' Yogyakarta. Jurnal Psikologi dan Ilmu Sosial (Proyeksi). 6(2): 12-20.

Wahid A. 2008. Dinamika Kelompok Tani Kegiatan Rehabilitasi Hutan dan Lahan di DAS Bila Walanae Desa Lasiwala Kabupaten Sidrap. Jurnal Hutan dan Masyarakat. 3(2): 149-157. [Internet]. [dapat diunduh dari: http:/journal.unhas.ac.id].

Yuliastuti IAN, Yasa INM, Jember IM. 2013. Partisipasi Masyarakat dalam Pengelolaan Sampah di Kabupaten Badung. Jurnal Ekonomi dan Bisnis Universitas Udayana. Vol. 2(6):374-393. 